\title{
Inklusi Sosial Penghayat Kepercayaan; Upaya Mendorong Hak Warga Negara Penganut Kepercayaan Sedulur Sikep Kudus
}

\author{
Ubbadul Adzkiya, Iman Fadhilah \\ Universitas Wahid Hasyim, Semarang \\ *Correspondence adress: adzkiya24@gmail.com

 \\ ISSN: $1979-4703(\mathrm{p})$ \\ ISSN: 2527-9726 (e) \\ Keywords: \\ Agama Lokal, \\ Diskriminasi, Inklusi \\ Sosial

\section{A B S T R A C T} \\ Indonesia has a diversity of religions and cultures, so far many people are still \\ discriminated against because they are different from the state's recognized \\ religion. In Kudus Regency, the Sedulur Sikep community as adherents of \\ Adam's religion could not register their marriage, thus facing population \\ administration problems. This service-based research explains how to strive for \\ them to gain access to public services, social acceptance, and policy changes so \\ that they are not discriminated against again. By connecting perspectives on civil \\ and political rights as well as economic, social and cultural. The results show \\ that the root of the problem which afflicts the victim can be spelled out in this \\ column, namely the administrative system of population causes humiliation on \\ the basis of the belief in participation that impacts on exclusion and other \\ exclusions. To overcome this problem, efforts and strategies that are commonly \\ made are changes at the internal level, empowerment, recognition and \\ acceptance.
}

\section{A B S T R A K}

Indonesia memiliki keragaman agama dan budaya, selama ini banyak masyarakat yang masih terdiskriminasi dikarenakan mereka berbeda dengan agama yang diakui negara. Di Kabupaten Kudus, masyarakat Sedulur Sikep sebagai penganut agama Adam tidak bisa mencatatkan perkawinannya, sehingga menghadapi masalah administrasi kependudukan. Penelitian berbasis pengabdian ini menjelaskan tentang bagaimana mengupayakan mereka untuk mendapat akses layanan publik, penerimaan sosial masyarakat, dan perubahan kebijakan agar mereka tidak terdiskriminasi kembali. Dengan menyambungkan perspektif hak sipil dan poliitik serta ekonomi, sosial dan budaya. Hasil menunjukkan bahwa maka akar dari persoalan yang menimpa penghayat bisa dijabarkan dalam lajur ini yaitu tata administrasi kependudukan menyebabkan penghinaan atas dasar keyakinan partisipasi yang berdampak pada pengucilan dan eksklusi lainnya. Untuk mengatasi masalah itu, maka upaya dan strategi yang umum dilakukan yaitu perubahan di tingkat internal, pemberdayaan, pengakuan dan penerimaan. 


\section{Pendahuluan}

Badan Koordinasi Pengawas Kepercayaan Masyarakat (Bakorpakem) pada tahun 2012 melansir data penghayat kepercayaan di Jawa Tengah. Terdapat 296 aliran kepercayaan, 43 diantaranya sudah tidak lagi aktif. Data tentang penghayat memang berbeda antara satu instansi dengan lainnya. Di Dinas Kebudayaan dan Pariwisata misalnya, pada tahun 2013 penghayat di Jawa Tengah berjumlah 188.127. Mereka tersebar di seluruh kabupaten maupun kota. Jika didasarkan pada eksistensi organisasinya, terdata 56 organisasi yang masih aktif, 8 tidak aktif dan 10 belum terinventarisir.

Jumlah tersebut tersebar di seluruh wilayah di Jawa Tengah. Beberapa diantara organisasi tersebut ada yang kantor pusatnya berada di Jawa Tengah seperti Ngesti Kasampurnan (Magelang), Kapribaden (Purworejo), Jawa Jawata (Pekalongan), Panunggalan (Surakarta), Cahya Buwana (Cilacap), Pakarti (Rembang), Mardi Santosaning Budhi (Temanggung), Maneges (Tegal), Paguyuban Budaya Bangsa (Kebumen), Liman Seto (Blora), Tri Tunggal Bayu (Banyumas), Kaweruh Jiwa (Semarang), dan banyak lagi. Di luar organisasi pusat, juga banyak terdapat organisasi cabang seperti Sapta Dharma dan Sumarah yang berpusat di Jogjakarta. Juga terdapat kelompok penghayat yang tidak mendaftarkan diri di Kesatuan Bangsa Politik dan Lingkungan Masyarakat (Kesbangpol dan Linmas) seperti Sedulur Sikep di Kudus, Pati dan Blora. Di luar penghayat yang berorganisasi ada juga penghayat yang tidak berorganisasi atau penghayat perorangan.

Beberapa praktek diskriminasi yang menimpa penghayat kami gambarkan secara singkat di sini. Penganut Sapta Darma di Kecamatan Larangan Kabupaten Brebes pada 2012 pernah didemo oleh warga setempat lantaran dianggap sesat. Pasalnya, ketika penganut Sapta Darma di Desa Kalenpandan Kecamatan Larangan mengadakan sujuduan (ritual, red) warga setempat yang diprovokatori oleh tokoh setempat yang menganggap bahwa agama Sapta Dhamo sesat karena sujud menghadap ke arah timur.

Selain penggrebegan, warga Sapta Darma Brebes lain yang berdomisili di Desa Sigentong Kecamatan Wanasari dipaksa oleh pegawai Kecamatan, Kapolsek, dan Kantor Urusan Agama (KUA) setempat untuk membuat tempat pemakaman sendiri. Pasalnya, menurut pejabat tingkat Kecamatan dan tokoh agama Islam Kecamatan Larangan pemeluk Sapta Darma tidak boleh dimakamkan di Tempat Pemakaman Umum (TPU).

Di Kabupaten Pati, Jawa Tengah, pelayanan publik kepada warga penghayat kepercayaan juga kerap mengalami persoalan. Hal demikian tercermin dari kasus yang terjadi di Desa Tegalwiru, Kecamatan Trangkil, Pati. Di desa ini, perangkat desa mulai kepala desa beserta perangkat desa lain tidak memberi pelayanan bagi warga penghayat yang meninggal dunia. Alih-alih melayani, mereka justru menginisiasi penolakan pemakaman warga penghayat.

Warga penghayat dari Sapta Darma yang meninggal bernama Marto Mardin di akhir tahun 2012. Dia meninggalkan sanak keluarga bernama Muri. Sang anak, Muri sangat kecewa dengan tindakan diskriminasi yang dilakukan oleh perangkat desa. Ketika 
berusaha memperjuangkan, dia justru diminta untuk pindah agama. Surat pernyataan yang sudah ditandatangani disebar ke warga sebanyak 100 lembar, tanpa ada salinan kepada yang bertanda tangan. Soal pemakaman berimbas pada pemaksaan untuk menjalankan keyakinan yang dianutnya.

Di Kudus, identitas agama di KTP dikosongkan. Mereka juga tidak terdaftar sebagai penghayat di Kesbangpolimnas, karena mereka merasa bukan penghayat. Mereka menegaskan diri sebagai penganut Agama Adam. Keturunan Sedulur Sikep, yang melestarikan ajaran ki Samin Surosentiko. Karena itu mereka enggan mengganti identitasnya sebagai penghayat. Karena mereka tidak terdaftar sebagai penghayat (karena mereka merasa bukan penghayat) maka mereka tak bisa mencatatkan perkawinannya. Syarat untuk bisa dicatatkan di catatan sipil dalam perkawinan adalah harus terdaftar di Kesbangpol. Selain itu harus ada tetua adat yang terdaftar juga di pemerintahan. Sehingga mereka sah ketika menikah menurut persefektif negara.

Pada intinya, penganut Sedulur Sikep tidak memenuhi persyaratan administrasi yang ditentukan negara, supaya perkawinannya bisa dicatatkan. Hingga akhirnya sudah berpuluh puluh tahun perkawinan mereka tak bisa dicatatkan. Mereka tak punya kutipan akta nikah sebagaimana mereka yang beragama resmi atau berkeyakinan sebagai penghayat. Saat ini, kurang lebih ada 20 kepala keluarga (KK) Sedulur Sikep di Kabupaten Kudus yang sudah melakukan perkawinan namun belum memiliki akta perkawinan. Mereka ketika bertanya kepada pejabat pemerintah Kabupaten Kudus, hanya mendapat jawaban bahwa untuk melayani mereka tak ada undang-undangnya. Sehingga sampai sekarang kelompok Sedulur Sikep tak mendapat pelayanan untuk mendapat akta perkawinan.

\section{Tinjauan Pustaka}

Penghayat Kepercayaan

Secara bahasa arti dari kepercayaan berasal dari kata percaya, menurut A.L. Huxley (dalam Departemen Pendidikan Dan Kebudayaan RI, 1992-1994) di dalam bukunya The Parennial Philosiphy, seseorang pengarang dan ahli filsafat dari Inggris, menyebutkan empat arti:

a. Percaya/mengandalkan (kepada orang tertentu).

b. Percaya (faith) kepada wibawa (dari para ahli di suatu bidang ilmu pengetahuan).

c. Percaya (beliefe) kepada dalil-dalil yang kita sendiri tidak dapat mengeceknya, apabila kita mempunyai kesediaan, kesempatan, dan kemampuan untuk itu.

d. Percaya (beliefe) kepada dalil-dalil, yang kita ketahui, bahwa kita tidak dapat mengeceknya, sekalipun kita menghendakinya.

Huxley berpendapat, bahwa ketiga arti yang pertama mempunyai peranan yang penting dalam kehidupan sehari-hari dan dalam arti yang keempat itu dipandangnya sama dengan apa yang biasa disebut "kepercayaan agamani". Aliran-aliran kepercayaan merupakan aliran kerohanian yang sulit didefinisikan secara tepat, sama sulitnya dengan mendefenisikan agama serta lembaga-lembaga kerohanian lainnya. As'ad (1982) mengatakan penghayat adalah suatu cabang dari pada paham yang rentannya masih 
berinduk dari salah satu agama (madzhab, orde, sekte dan lain-lain). Di Indonesia salah satu masalah yang tak kunjung menemukan titik temu adalah saat mengurai agama dan kepercayaan. Dalam dokumen internasional kita mengenal religion dan belief yang sering diterjemahkan dengan kata "agama" dan "keyakinan." Dalam pasal 29 kata "agama" dan "kepercayaan" muncul. Perdebatannya adalah apakah keduanya merupakan dua substansi atau satu (Kholiludin: 2008).

Persoalan menjadi tambah pelik karena yang terjadi kemudian adalah terjadi pemisahan secara diametral antara agama dan kepercayaan. Diversifikasi ini, menjadi salah satu cara yang ampuh untuk mengatakan bahwa kepercayaan berbeda dengan agama, bahkan bukan agama. Lebih tegas Tedi Tholiludin (2013) bahwa pembedaan agama dengan kepercayaan, tidak ditopang oleh bangunan argumentasi yang kuat secara epistemik maupun metodologis. Besar kemungkinan yang terjadi adalah pemisahan kategorial dengan didasarkan atas kepentingan politis. Indikasinya, negara hanya mengakui enam agama, sementara aliran kepercayaan dianggap bukan agama. Padahal kalau yang menjadi referensi adalah bahasan-bahasan mengenai agama dan kepercayaan dalam tradisi akademik, pembedaan yang dilakukan negara, sangatlah tidak tepat.

Menurut Peraturan Bersama Menteri Dalam Negeri dan Menteri Kebudayaan dan Pariwisata definisi Penghayat Kepercayaan adalah setiap orang yang mengakui dan meyakini nilai-nilai penghayatan kepercayaan terhadap Tuhan Yang Maha Esa. Kepercayaan terhadap Tuhan Yang Maha Esa adalah pernyataan dan pelaksanaan hubungan pribadi dengan Tuhan Yang Maha Esa berdasarkan keyakinan yang diwujudkan dengan perilaku ketaqwaan dan peribadatan terhadap Tuhan Yang Maha Esa serta pengamalan budi luhur yang ajarannya bersumber dari kearifan lokal bangsa Indonesia.

Jadi Aliran Kepercayaan yang berkembang di masyarakat adalah sesuatu yang bersumber kepada budaya luhur bangsa Indonesia yang mengandung nilai-nilai luhur dan telah membudaya dalam masyarakat sebagai hasil penalaran daya cipta, karsa dan rasa manusia, yang berbentuk atau berwujud kepercayaan budaya, meliputi aliran kebatinan, kejiwaan, kerohanian atau kepercayaan terhadap Tuhan Yang Maha Esa. Kepercayaan terhadap Tuhan Yang Maha Esa tidak merupakan agama dan tidak mengarah kepada pembentukan agama baru, dalam arti bahwa indentitas tuntunan yang dianut adalah produk interaksi bebas dalam menghayati keterlibatan atau keterjalinan hubungan dan keterkaitan atau ketergantungan hidup manusia dengan Tuhan Yang Maha Esa.

\section{Inklusi Sosial}

Inklusi sosial adalah upaya menempatkan martabat dan kemandirian individu sebagai modal utama untuk mencapai kualitas hidup yang ideal. Melalui inklusi sosial, Program Peduli mendorong agar seluruh elemen masyarakat mendapat perlakuan yang setara dan memperoleh kesempatan yang sama sebagai warga negara terlepas dari perbedaan apapun (Program Peduli, 2015). Inklusi sosial sebagai proses untuk meningkatkan partisipasi individu dan kelompok dalam kegiatan masyarakat, dimana pendidikan merupakan bagiannya, menjadi salah satu perhatian utama kemitraan 
Pemerintah Republik Indonesia dan Pemerintah Australia. Ini selaras dengan kebijakan pendidikan Indonesia dan kebijakan dukungan Australia bagi pembangunan secara umum (Lokakarya Penyusunan Kerangka Kerja Inklusi Sosial, 2015).

Pengertian inklusi digunakan sebagai sebuah pendekatan untuk membangun dan mengembangkan sebuah lingkungan yang semakin terbuka; mengajak masuk dan mengikutsertakan semua orang dengan berbagai perbedaan latar belakang, karakteristik, kemampuan, status, kondisi, etnis, budaya dan lainnya. Terbuka dalam konsep lingkungan inklusi, berarti semua orang yang tinggal, berada dan beraktivitas dalam lingkungan keluarga, sekolah ataupun masyarakat merasa aman dan nyaman mendapatkan hak dan melaksanakan kewajibannya. Jadi, lingkungan inklusi adalah lingkungan sosial masyarakat yang terbuka, ramah, meniadakan hambatan dan menyenangkan karena setiap warga masyarakat tanpa terkecuali saling menghargai dan merangku

Inklusi membawa perubahan sederhana dan praktis dalam kehidupan masyarakat. Sebagai bagian dari masyarakat, kita menginginkan tinggal dalam lingkungan masyarakat yang memberikan rasa aman dan nyaman, yang memberikan peluang untuk berkembang sesuai minat dan bakatnya, sesuai cara belajarnya yang terbaik, yang mengupayakan kemudahan untuk melaksanakan kewajiban dan mendapatkan hak sebagai warga masyarakat. Jadi, masyarakat inklusi adalah masyarakat yang terbuka dan universal serta ramah bagi semua, yang setiap anggotanya saling mengakui keberadaan, menghargai dan mengikutsertakan perbedaan. Setiap warga masyarakat inklusi, baik yang memiliki perbedaan pada umumnya maupun yang memiliki perbedaan khusus yang sangat menonjol, punya tanggung jawab lewat perannya masing-masing dalam mengupayakan kemudahan, agar setiap warga masyarakat secara inklusif dapat memenuhi kebutuhannya, melaksanakan kewajibannya dan mendapatkan haknya terhadap semua bidang kehidupan bermasyarakat dan berbangsa (DAKSA Foundation, 2015). Adapun bentuk - bentuk inklusi sosial yaitu:

1. Keberadaannya diakui oleh negara (Pemerintah dan Masyarakat).

a. Pengakuan (Recognition) antara lain melalui upaya-upaya:

b. Anak jalanan harus didorong memiliki KTP dan tidak ada diskriminasi untuk pembuatan KTP.

c. Semua warga, (khususnya kelompok penerima manfaat) berhak mendapatkan akte kelahiran yang dikeluarkan pemerintah daerah setempat

d. Pemerintah daerah menyusun peraturan daerah, atau perbup/perwali untuk mengakui keberadaan (kelompok penerima manfaat) itu dan sama hak serta kewajibannya dengan yang lain.

e. Negara khususnya pemerintah (kelompok penerima manfaat) mengeluarkan Kebijakan untuk pengakuan atas keberadaan tersebut

2. Hak - hak dasarnya dihormati (Respecting Basic Right)

a. Pemenuhan Hak Dasar masyarakat yang diambil dari Piagam Hak Asasi Manusia (TAP MPR No. XVII/MPR/1998 Tentang Hak Asasi Manusia harus dijamin oleh semua pihak untuk dapat dipenuhi untuk (kelompok penerima manfaat) tersebut. 
b. Pembukaan akses bagi (kelompok penerima manfaat) pada fasilitas umum (administrasi, kesehatan, pendidikan, keamanan, ekonomi dan sosial budaya) dan berbagai bantuan Pemerintah dan Pemerintah daerah terkait.

c. Penjaminan dari pemerintah agar (kelompok penerima manfaat) terlibat dan berpartisipasi aktif dalam Implementasi UU Desa.

3. Didorong untuk membangun kemitraan dengan kelompok masyarakat (Building Mutual Partnership), antara lain
a. Meningkatkan ketrampilan untuk hidup (sustainable livelibood).
b. Mengembangkan kegiatan produktif yang berbasis pemanfaatan potensi lokal.
c. Mengembangkan kegiatan berbasis pendayagunaan kearifan lokal.
d. Membangun kemitraan yang saling menguntungkan dengan semua pihak.

4. Dipandang sebagai saudara sebangsa dan setanah air.

a. Integrasi Sosial, tidak ada lagi pemberian stigma sosial negatif kepada semua kelompok sosial.

b. Membangun "Masyarakat yang saling asah, saling asuh dan saling asih" tanpa mempersoalkan perbedaan dalam agama, keyakinan, kepercayaan, status sosial, etnis, ras, ciri fisik, keragaman sosial budaya.

c. Membangun semangat gotong-royong, kerelawanan sosial dan kewirausahaan sosial (social entrepreneurships).

Metode dan alat memobilisasi aset untuk pemberdayaan masyarakat melalui Asset Based Community Development (ABCD), antara lain:

1. Penemuan Apresiatif (Appreciative Inquiry)

Appreciative Inquiry (AI) adalah cara yang positif untuk melakukan perubahan organisasi berdasarkan asumsi yang sederhana yaitu bahwa setiap organisasi memiliki sesuatu yang dapat bekerja dengan baik, sesuatu yang menjadikan organisasi hidup, efektif dan berhasil, serta menghubungkan organisasi tersebut dengan komunitas dan stakeholdernya dengan cara yang sehat (Salahuddin dkk, 2015).

2. Pemetaan Komunitas (Community Mapping)

Pendekatan atau cara untuk memperluas akses ke pengetahuan lokal. Community map merupakan visualisasi pengetahuan dan persepsi berbasis masyarakat mendorong pertukaran informasi dan menyetarakan bagi semua masyarakat untuk berpartisipasi dalam proses yang mempengaruhi lingkungan dan hidup mereka (Dereau, 2013).

3. Pemetaan Asosiasi dan Institusi

Asosiasi merupakan proses interaksi yang mendasari terbentuknya lembagalembaga sosial yang terbentuk karena memenuhi faktor-faktor sebagai berikut:

a. kesadaran akan kondisi yang sama,

b. adanya relasi sosial,

c. orientasi pada tujuan yang telah ditentukan (Soetomo.2009).

\section{Model Pemberdayaan}

Pendampingan perempuan di Dusun Salakan menggunakan model pemberdayaan Asset Based Communities Development (ABCD). ABCD merupakan model pendekatan dalam 
pengembangan masyarakat. Pendekatan ini menekankan pada inventarisasi asset yang terdapat di dalam masyarakat yang dipandang mendukung pada kegiatan pemberdayaan masyarakat (Ahmad, 2007). Masyarakat merupakan aset yang berharga bagi sebuah desa. Adanya pemuda merupakan generasi penerus untuk melanjutkan dan mengisi perjuangan yang berlangsung atau yang akan datang. Kesamaan visi untuk keluar dari diskriminasi masyarakat penghayat sedulur sikep dapat diakumulasikan sebagai modal utama untuk bergerak, menjadikan mereka berdaya dalam kehidupan interaksi antar sesama warga negara. Dalam Metode ABCD memiliki lima langkah kunci untuk melakukan proses riset pendampingan diantaranya (Dereau, 2013).

1. Discovery (Menemukan)

Tahap awal pendampingan dengan menemukan permasalahan yang nantinya menjadi materi untuk dapat dikaji dan dijadikan sebagai kontribusi dalam memecahkan permasalahan diskriminasi warga dampingan. Langkah yang ditempuh melalui wawancara, observasi, serta dokumentasi.

2. Dream (Impian)

Dengan cara yang kreatif dan secara kolektif melihat masa depan yang mungkin terwujud, apa yang sangat dihargai dikaitkan dengan apa yang paling diinginkan. Pada tahap ini, setiap orang mengeksplorasi harapan dan impian mereka baik untuk diri mereka sendiri maupun untuk organisasi. Setelah melakukan diskusi kepada masyarakat penghayat kepercayaan, pendamping mulai mengetahui impian atau keinginan masyarakat dampingan. Setelah mengetahui keinginan atau impian maka langkah selanjutnya yaitu merancang sebuah kegiatan untuk memenuhi impian masyarakat.

3. Design (Merancang)

Proses di mana seluruh komunitas (atau kelompok) terlibat dalam proses belajar tentang kekuatan atau aset yang dimiliki agar bisa mulai memanfaatkannya untuk mencapai aspirasi dan tujuan seperti yang sudah ditetapkan sendiri.

4. Define (Menentukan)

Kelompok sebaiknya menentukan 'pilihan topik positif: tujuan dari proses pencarian atau deskripsi mengenai perubahan yang diinginkan.

5. Destiny (Lakukan)

Langkah yang terakhir adalah melaksanakan kegiatan yang sudah disepakati untuk memenuhi impian masyarakat dari pemanfaatan aset baik berupa semangat atau kesamaan visi dan harapan. Selain untuk memenuhi impian masyarakat untuk memperbaiki kehidupan agar menjadi lebih baik.

\section{Hasil dan Pembahasan \\ Problem Akses Layanan Sosial}

Pertama, akta kelahiran adalah identitas yang awajib dimiliki oleh setiap warga negara Indonesia, tanpa terkecuali. Sedulur Sikep selama ini mengalami persoalan dalam masalah Administrasi Kependudukan, dari KTP, Akta Nikah, Akta Kelahiran, Kartu Keluarga, dan produk administrasi kependudukan lainnya yang diterbitkan pemerintah. 
Sedulur Sikep sebagai penganut agama Adam menginginkan mereka mendapat haknya layaknya masyarakat umum, dalam hal akta kelahiran Sedulur Sikep menghadapi masalah dalam pencatatan di Akta Kelahiran, yaitu ditulis "telah lahir anak luar kawin". Padahal secara umum akta kelahiran biasanya tertulis "telah lahir anak dari pasanan suami-isteri". Dari hasil pendataan mayoritas anak dari Sedulur Sikep menerima akta kelahiran yang tertulis anak di luar kawin, atau ditulis Bin Ibu dari pasangan di luar kawin. Sebagai contoh semisal anak dari Budi Santoso, dalam akta kelahiran anaknya tertulis "telah lahir Sarah Puji Rahayu anak ke satu, perempuan luar kawin dari Tianah". Sebetulnya secara layanan mereka bisa mendapatkan akta kelahiran, namun yang menjadi permasalahan adalah pada redaksi yang tertera di dalamnya. Pemerintah masih mensyaratkan orang tua dari anak mempunyai status agama yang "diakui" oleh negara, sedang sedulur sikep selama ini menganut agama Adam, agama lokal yang menjadi warisan dari nenek moyangnya. Kesimpulan sementara terkait permasalahan ini adalah pada level kebijakan adminduk, yang menjadi wewenang pemerintah pusat untuk merubahnya. Di level desa hingga kabupaten, para petugas siap melayani sedulur sikep ketika peraturan payungnya sudah ada.

Kedua, masalah pendidikan agama bagi anak-anak penghayat hampir selalu menjadi problem di setiap wilayah, serta di tingkat satuan pendidikan dimana penghayat berada. Karena mereka tidak diakui sebagai agama yang diakui negara, maka mereka tidak mendapat layanan pendidikan yang ada di sekolah. Hal ini juga dihadapi Sedulur Sikep di Kabupaten Kudus. Budi Santoso menceritakan kronologi kejadian sejak menyekolahkan anak-anaknya pada tahun 2009 hingga kakaknya, Maskad, menyekolahkan anaknya, yang juga berarti keponakan Budi pada tahun 2012. Budi menyekolahkan dua anak putrinya. Sejak awal mendaftarkan anaknya, Budi sudah menyampaikan ke kepala sekolah beserta wakil kepala sekolah dengan apa adanya. Bahwa ia merupakan penganut ajaran Samin atau agamanya yang dianutnya adalah agama Adam. Budi, meskipun beragama Adam, tapi ia sangat ingin menyekolahkan anaknya ke sekolah umum. Dengan ia beragama Adam sebagai agama yang tidak diakui negara, kemudian Budi bertanya kepada kepala sekolah apa bisa diterima kedua anaknya bersekolah? Kemudian pihak sekolah, yang dalam hal ini diwakili oleh kepala sekolah menejawab, bahwa anak-anak Samin boleh bersekolah. Dengan adanya tanggapan dari pihak sekolah seperti itu, kemudian Budi berniat menyekolahkan kedua anaknya di sekolah tersebut. Dengan satu permintaan dari Budi, kalau nanti dalam proses belajar mengajar atau ujian agama atau yang lainnya bukan dalam hal agama Adam, Budi meminta agar anaknya tidak dipaksa untuk mengikutinya. Namun dalam perjalanannya, anak-anak dari sedulur sikep sempat dipaksa untuk belajar agama yang diakuin negara. Terkait dengan pemaksaan belajar agama yang diakui negara, berdasarkan pada laporan eLSA dan wakil dari Sedulur Sikep sudah melakukan advokasi. Hasil dari audiensi anak-anak sedulur sikep yang sedang menempuh pendidikan formal tidak dipaksa untuk ikut jam belajar Agama yang di akui negara di sekolah, mereka diberi kebebasan untuk tidak ikut dalam kelas tersebut. Mereka diberi waktu untuk belajar sendiri di Perpustakaan. Namun yang menjadi harapan dari Sedulur Sikep adalah mereka mendapat pelajaran agama sesuai dengan keyakinannya, yakni agama Adam. Sampai sekarang harapan itu belum terpenuhi, berdasarkan hasil audiensi mereka 
mengembalikan itu pada aturan induk tentang pengakuan agama resmi dari negara, sehingga Sedulur Sikep belum bisa dilayani dalam pendidikan agama yang sesuai keyakinannya.

Ketiga, pengajuan Kredit ke Bank Ditolak/ kesulitan Mendapatkan Layanan Jasa Finansial. Dalam Kartu Kelurga (KK) Sedulur Sikep Kudus kepala keluarga tertera seorang ibu. Ayah sama sekali tak mempunyai peran. Ini merupakan imbas dari perkawinan yang tidak bisa dicatatkan. Akhirnya, ketika membuat kartu keluarga mereka tak bisa melampirkan akta nikah. Akibat tidak bisa melampirkan akta nikah, maka dalam KK ditulis yang menjadi kepala keluarga adalah ibunya. Akibat dari kepala keluarga seorang ibu kemudian mempunyai dampak yang sangat besar. Bukan hanya stigma soal menikah yang tidak sah, namun ternyata kemudian ada dampak yang lebih mengancam terhadap perekonomian. Ancaman itu datang bagi Sedulur Sikep ketika mereka mencoba untuk meminjam uang ke Lembaga Keuangan dan ke bank. Ternyata, karena dalam kartu keluarga yang menjadi kepala keluarga seorang ibu, mereka tak bisa meminjam uang. Pengajuan pinjaman pada dasarnya adalah karena kebutuhan tambahan dana sebagai modal untuk menjalankan usaha, modal memang menjadi masalah utama yang dialami setiap masyarakat.

\section{Problem Penerimaan Sosial}

Pertama, masalah stigma tidak beragama.Sebagian masyarakat Kudus mempunyai istilah khusus ketika mengatakan orang bodoh yaitu "dasar orang samin." Orang Samin masih dipandang sebelah mata sebagai orang bodoh, ngeyelan (menyangkal), sulit diatur, dan label negatif lainnya. Hal ini tentu saja menjadikan ketidaknyamanan sedulur sikep dalam kehidupan bermasyarakat, meski mereka di level desa sangat harmonis hubungannya dengan masyarakat lain non sedulur sikep. Namun masyarakat umum di luar desa, dan sebagian di desa tersebut masih memandang negatif Sedulur Sikep.Tentu saja ini bagian akibat dari pemisahan antara agama yang diakui dan tidak diakui, sehingga secara otomatis wacana di masyarakat mengakar tentang perspektif tersebut. Masyarakat masih menganggap bahwa sedulur sikep adalah komunitas yang tak beragama, mereka adalah komunitas yang melakukan 'kumpul kebo'. Kegiatan lain sebagai upaya untuk menghilangkan stigma tersebut adalah dengan melibatkan Sedulur Sikep dalam forumforum tingkat regional sampai nasional, dalam level nasional, tokoh sedulur sikep diikutkan dalam pertemuan solidaritas korban kebebasan beragama dan berkayakinan. Di level regional mendorong Sedulur Sikep untuk aktif dalam kegiatan lintas iman di kabupaten Kudus, salah satu di antara mereka masuk dalam pengurus harian komunitas lintas iman Kudus. Para pemuda/pemudi juga dilibatkan dalam komunitas lintas iman, dengan bentuk kegiatan bentuk damai yang diselenggarakan rutin pertahun. Sedulur Sikep turut serta menjadi peserta aktif, hal ini sebagai upaya untuk mensosialisasikan dirinya ke khalayak umum.

Kedua, tidak dilibatkan dalam musyawarah desa. Warga Sedulur Sikep di Kudus, khususnya di Desa Larikrejo tidak dilibatkan dalam kegiatan musyawarah desa dan kegiatan desa lainnya.Selain itu juga karena keterbatasan pendidikan/tidak memiliki ijazah 
mereka terhalang syarat administrasi ketika ingin mengajukan diri menjadi anggota BPD (Badan Permusyawatan Desa). Di Desa Larikrejo, sedulur sikep diakui keberadaannya oleh pemerintah desa, namun memang belum diikutkan dalam permusyarawahan yang diselenggakan desa. Meski Budi Santoso, tokoh Sedulur Sikep selalu ikut dalam kegiatan desa, adalah karena kapasitasnya sebagai Ketua RW di desa larikrejo. Selama ini belum ada undangan resmi mengatasnamakan sedulur sikep di wilayah tersebut.

Ketiga, kebijakan adminduk dan problem "agama resmi". Sedulur sikep mengalami problem yang pelik dalam hal administrasi kependudukan, diskriminasi yang mereka dapatkan dari negara, yakni berupa undang undang. Perangkat aturan terkait dengan pengakuan agama, pendidikan dan perkawinan inilah yang membuat warga Sedulur Sikep tak bisa berbuat banyak. Dalam segala persoalan mereka lengkap mengalami diskriminasi. Paling tidak ada lima jenis diskriminasi yang mereka alami, yakni; pendidikan, kolom agama di KTP, pencatatan perkawinan, akta kelahiran, dan Kartu Keluarga (KK).Selama ini dalam masalah pencatatan perkawinan sesuai dengan undang-undang nomor 1 tahun 1974 adalah sah jika dilakukan sesuai dengan agama dan kepercayaannya itu. Bagi yang beragama Islam, untuk mencatatkan perkawinan terdaptar di Kantor Urusan Agama (KUA). Untuk non-Muslim dan penganut aliran kepercayaan dicatatkan di Catatan Sipil. Ini sesuai dengan peraturan pemerintah nomor 37 tahun 2007. Untuk Sedulur Sikep dengan keyakinan agama Adam (diluar agama resmi), akhirnya tidak bisa dicatatkan karena tidak menganut agama resmi menurut pemerintah atau aliran kepercayaan. Penganut ajaran Samin atau Sedulur Sikep, Kabupaten Kudus menghendaki kolom agama dalam Kartu Tanda Penduduk (KTP) ditulis Agama Adam. Permintaan itu berdasarkan keyakinan yang mereka anut, yakni Agama Adam.

Imbas perkawinan yang tak bisa dicatatkan, akta kelahiran anak-anak Sedulur Sikep penisbatan kepada orang tua (bin) kepada akhirnya kepada ibunya. Karena tidak bisa melampirkan akta nikah ketika membuat akta kelahiran, maka anak Sedulur Sikep dianggap tak mempunyai ayah oleh Catatan Sipil Kabupaten Kudus. Akhirnya penisbatannya kepada seorag ibu, bukan kepada bapak. Dalam Kartu Keluarga (KK) Sedulur Sikep Kudus, kepala keluarga tertera seorang ibu. Ayah sama sekali tak mempunyai peran. Ini merupakan imbas dari perkawinan yang tidak bisa dicatatkan. Akhirnya, ketika membuat kartu keluarga mereka tak bisa melampirkan akta nikah. Akibat tidak bisa melampirkan akta nikah, maka dalam KK ditulis yang menjadi kepala keluarga adalah ibunya. Problem di atas yang dialami Sedulur Sikep, sejatinya merupakan problem secara nasional. Pokok persoalan yang tertera dalam UU No. 1/PNPS Tahun 1965 dan adanya kebijakan tidak mengakui adanya agama baru serta mengakui dan tidak mengakui merupakan problem mendasar yang mengakibatkan terjadinya disrkiminasi dan pelanggaran hak dasar penganut kepercayaan.

\section{Kesimpulan}

Berdasarkan pada penjelasan sebelumnya, maka akar dari persoalan yang menimpa penghayat bisa dijabarkan dalam lajur ini yaitu tata Administrasi Kependudukan menyebabkan penghinaan atas dasar keyakinan Partisipasi yang berdampak 
padaPengucilan dan eksklusi lainnya. Untuk mengatasi masalah itu, maka upaya dan strategi yang umum dilakukan adalah: Perubahan di tingkat internal, Pemberdayaan, Pengakuan dan Penerimaan. Dari sini kemudian muncul beberapa pertanyaan: apakah pengakuan dan penerimaan itu bisa dilakukan di level internal atau perlu melihat batas wilayah advokasi yang dikaitkan dengan gerakan atau advokasi yang lebih besar. Persoalan yang beragam tentu dibutuhkan strategi yang beragam. Ada kasus-kasus yang bermasalah dilevel implementasi sehingga hanya perlu advokasi di level lokal, tetapi juga ada masalah yang kemudian perlu pemecahan di tingkatan yang lebih luas karena menyangkut pembenahan secara sistemik. Hubungan antara pemerintah dan warga negara tidak lagi bergantung pada kemauan dalam memenuhi kebutuhan. Sebaliknya pemerintah memiliki tanggung jawab untuk memastikan terpenuhinya hak masyarakat dan masyarakat memenuhi tanggung jawab ke pemerintah.

\section{Daftar Pustaka}

L Pals, Daniel, 2006. Dekontruksi Kebenaran; Kritik Tujuh Teori Agama, Yogyakarta: IRCiSoD

Kholiludin, Tedi, dkk., 2012. Laporan Tahunan Kebebasan Beragama dan Berkeyakinan di Jawa Tengah, Semarang: eLSA

Kholiludin, Tedi, dkk., 2015. Inklusi Sosial Penghayat Kepercayaan, Semarang: eLSA

Sumanto, 2010. Baik Buruk Agama; Jalan Menuju dialog,http://elsaonline.com/?p=228

Iwan Sukoco dan Herwan Abdul Muhyi. 2015. Ecopreneurship Dalam Menumbubkan Usaha Berwawasan Lingkungan Pada Sentra Industri Penyamakan Kulit Sukaregang Kabupaten Garut. Jurnal Sosiohumaniora. Volume 17 No. 2 Juli 2015. Hal. 158

Nadhir Salahuddin dkk. 2015. Panduan KKN ABCD. UIN Sunan Ampel Surabaya.

Christoper Dereau. 2013. Pembaru dan Kekuatan Lokal untuk Pembangunan, Australian Community Development and Civil Society Strengthening Scheme (ACCESS) Phase II, Agustus. hal. 36

Soetomo.2009. Pembangunan Masyarakat, Yogyakarta: Pustaka Pelajar.

Munawar Ahmad. 2007. Asset Based Communities Development (Abcd): Tipologikkn Partisipatif Uin Sunan Kalijaga Studi Kasus Pelaksanaan KKN ke-61 di Dusun Ngreco Surocolo, Selohardjo Pundong, Bantul Tahun Akademik 2007. Aplikasia, Jurnal Aplikasi ilmu ilmu Agama, Vol. VIII, No. 2 Desember2007. hal. 104 